\title{
Animasi Prosedur Pendaftaran Calon Mahasiswa Baru Universitas Sam Ratulangi dengan Augmented Reality
}

\author{
Riki Satria Watulingas, A.S.M. Lumenta, Alwin Sambul \\ Teknik Informatika Universitas Sam Ratulangi Manado, Indonesia. \\ riki_watulingas@live.com, al@unsrat.ac.id, asambul@gmail.com
}

\begin{abstract}
Abstrak - Universitas Sam Ratulangi Manado (Unsrat) merupakan salah satu perguruan tinggi negeri favorit yang berada di provinsi Sulawesi Utara. Setiap tahun terdapat belasan ribu pendaftar dari berbagai daerah di Indonesia. Kurangnya media sosialisasi untuk para calon mahasiswa baru mengenai langkah demi langkah yang harus dilakukan untuk bisa terdaftar secara resmi sebagai mahasiswa di Universitas Sam Ratulangi Manado seringkali menyebabkan para pendaftar merasa kesulitan untuk melakukan pendaftaran. Penelitian dengan judul "Animasi Prosedur Pendaftaran Calon Mahasiswa Baru Universitas Sam Ratulangi dengan Augmented Reality" menghasilkan sebuah aplikasi yang di ciptakan dengan pendekatan metode Multimedia Development Life Cycle untuk memberikan informasi prosedur pendaftaran calon mahasiswa baru dengan cara yang menarik dan mudah untuk dipahami.
\end{abstract}

Kata kunci : Augmented Reality, Multimedia

Development Life Cycle, Android

\section{PENDAHULUAN}

Universitas Sam Ratulangi (Unsrat) adalah perguruan tinggi negeri di Sulawesi Utara yang memiliki 11 fakultas dan 1 program pasca sarjana. Unsrat ditetapkan sebagai salah satu Perguruan Tinggi Negara (PTN) sejak tanggal 14 September 1965. Setiap Tahun Unsrat melakukan penerimaan mahasiswa baru dari berbagai daerah melalui jalur penerimaan SNMPTN, SBMPTN, Tumou Tuo (T2), dan SUMIKOLAH. Data dari situs dashboard Unsrat Manado menunjukan bahwa pada 5 tahun terakhir yaitu dari tahun 2013 sampai dengan tahun 2017, jumlah ratarata pendaftar untuk program pendidikan strata 1 (S1) mencapai angka 15.441 (lima belas ribu empat ratus empat puluh satu) pendaftar yang berasal dari berbagai propisnsi di Indonesia.

Kurangnya media sosialisasi untuk para calon mahasiswa baru mengenai langkah-langkah dalam melakukan pendaftaran di Unsrat menyebabkan mereka merasa kesulitan dalam melakukan pendaftaran. Para pendaftar merasa kebingungan dalam mencari tahu informasi langkah demi langkah yang harus dilakukan untuk bisa terdaftar secara resmi di Unsrat. Teknologi Augmented Reality dan animasi adalah pasangan teknologi yang bisa digunakan untuk memberikan informasi yang jelas secara menarik dan mudah dipahami oleh para calon mahasiswa baru yang ingin mendaftarkan diri mereka di Unsrat. Dari hasil pembahasan di atas, maka peneliti akan mengembangkan aplikasi augmented reality yang dapat menampilkan video animasi prosedur langkah-langkah pendaftaran calon mahasiswa baru Unsrat Manado.

\section{LANDASAN TEORI}

\section{A. Universitas Sam Ratulangi Manado}

Universitas Sam Ratulangi Manado atau biasa disebut Unsrat adalah salah satu perguruan tinggi negeri favorit yang berada di Sulawesi Utara. Universitas Sam Ratulangi secara resmi berstatus Universitas Negeri pada tahun 1961. Nama Sam Ratulangi di ambil dari nama pahlawan nasional Indonesia yang berasal provinsi Sulawesi Utara. Dr.Gerungan Saul Samuel Jacob Ratulangi biasa di pangil dengan Sam, merupakan maha putera Indonesia yang dilahirkan di Tondano, ibukota kabupaten Minahasa. Setiap Tahun Unsrat melakukan penerimaan mahasiswa baru dari berbagai daerah melalui jalur penerimaan SNMPTN, SBMPTN, Tumou Tuo (T2), dan SUMIKOLAH.

\section{B. Jalur Penerimaan Mahasiswa baru}

Unsrat pada dasarnya memiliki 4 jalur penerimaan mahasiswa, yaitu Seleksi Nasional Masuk Perguruan Tinggi Negeri (SNMPTN), Seleksi Bersama Masuk Perguruan Tinggi Negara (SBMPTN), Tumou Tou (T2), dan Sumikolah, namun untuk tahun 2017, Unsrat sudah tidak membuka penerimaan melalui jalur Sumikolah.

1. SNMPTN Seleksi Nasional Masuk Perguruan Tinggi Negeri adalah jalur penerimaan mahasiswa baru oleh perguruan tinggi negeri yang dilaksanakan serentak seluruh Indonesia. SNMPTN melakukan seleksi berdasarkan hasil penelusuran prestasi akademik dengan menggunakan rapor semester 1 (satu) sampai dengan semester 5 (lima) bagi SMA/SMK/MA atau masa belajar 3 (tiga tahun) atau semester 1 (satu) sampai dengan semester 7 (tujuh) bagi SMK dengan masa belajar 4 (empat) tahun, serta portfolio akademik. Melalui jalur penerimaan ini, siswa yang berprestasi tinggi dan konsisten prestasinya layak mendapatkan kesempatan untuk melanjutkan pendidikan di perguruan tinggi negeri..

2. SBMPTN Seleksi Bersama Masuk Perguruan Tinggi Negeri adalah jalur penerimaan mahasiswa baru di perguruam tinggi negeri dengan melakukan seleksi berdasarkan hasil ujian tertulis dan ujian keterampilan, yang dapat diikuti oleh siswa dari lulusah menengah (SMA/MA/SMK) dan sederajat. SBMPTN bertujuan untuk menyeleksi calon mahasiswa yang diprediksi mampu meyelesaikan studi di perguruan tinggi dengan baik, dan memberi kesempatan bagi calon mahasiswa untuk memilih lebih dari satu PTN lintas wilayah. 
3. Tumou Tou (T2) merupakan jalur penerimaan lokal yang dilaksanakan langsung oleh Unsrat. Hasil seleksi jalur penerimaan T2 diperolah melalui ujian tertulis.

\section{Augmented Reality (AR)}

Augmented reality didefinisikan sebagai penggabungan benda-benda nyata dan maya di lingkungan nyata, berjalan secara interaktif dalam waktu nyata, dan terdapat terdapat integrasi antar benda dalam tiga dimensi, yaitu benda maya terintegrasi dalam dunia nyata (Ronald T. Azuma, 1997). Augmented Reality pada dasarnya memiliki 3 karakteristik utama sebagai berikut.

1. Mengkombinasikan kenyataan dan objek virtual dalam lingkungan nyata 3D (real environment)

2. Berjalan secara interaktif dan waktu yang nyata (real time)

3. Terdapat integrasi antar benda dalam tiga dimensi, yaitu benda maya terintegrasi dalam dunia nyata.

\section{Animasi}

Animasi memiliki banyak sekali definisi karena setiap tahun para animator, ahli sejarah, dan pakar teori di bidang animasi memberikan banyak sekali definisi berbeda tentang animasi. Phil Denslow dalam jurnalnya yang dipublikasikan di Fourth Society for Animation Studies Conference pada bulan oktober tahun 1992 juga menyatakan bahwa ada banyak definisi tentang animasi. Oxford Dictionary mendefinisikan animasi sebagai sebuah film yang seolah hidup, terbuat dari fotografi, gambaran, boneka, dan sebagainya dengan perbedaan tipis antar frames, untuk memberi kesan pergerakan saat diproyeksikan (The Little Oxford Dictionary, 19). Brian wells dalam jurnal freme of reference: toward a definition of animation memberi pedoman bahwa animasi adalah media komunikasi visual.

\section{E. Animasi 2 Dimensi}

Animasi 2 dimensi dapat juga dikatakan animasi kartun, yang mana terbentuk pada dimensi panjang dan lebar dalam satu bidang datar, jadi hanya ada panjang dan lebar saja tanpa adanya dimensi tebal. Bidang dua dimensi dapat digambarkan dengan sumbu $\mathrm{X}$ dan $\mathrm{Y}$. Dari keterangan diatas dapat disimpulkan bahwa animasi 2D adalah sebuah kumpulan gambar dimensi panjang dan lebar yang berkaitan hingga menciptakan suatu gerakan bila diproyeksikan sehingga gambar terlihat seolah-olah hidup..

\section{F. Android}

Android adalah system operasi berbasis Linux bersifat open source yang dibuat untuk perangkat seluler ponsel pintar dan komputer tablet. Sifat open source android memberikan kesempatan bagi pengembang untuk menciptakan atau mengembangkan aplikasinya. Android pada awalnya dikembangkan oleh Android, Inc, dengan dukungan finansial dari google yang kemudian diakuisisi secara resmi oleh Google pada tahun 2005. Sistem operasi android secara resmi dirilis pada tahun 2007. Sifat keterbukaan sistem operasi android menjadikan sistem operasi ini favorit dari pengguna dan pengembang. Android berpengaruh besar terhadap pertumuhan konsumsi aplikasi mobile.

\section{G. Multimedia}

Multimedia adalah kombinasi dari komputer dan video (Rosch, 1996) atau secara umum, Multimedia merupakan kombinasi 3 elemen, yaitu suara, gambar, dan teks (McCormick, 1996) atau Multimedia adalah kombinasi dari paling sedikit dua media input atau output dari data, media ini dapat berupa audio (suara, musik), animasi, video, teks, grafik, dan gambar (Turban dkk, 2002).

\section{H. Multimedia Development Life Cycle}

Multimedia Development Life Cycle pada dasarnya adalah proses-proses dalam mengembangkan perangkat lunak berbasis multimedia. Metode pengembangan multimedia diperkenalkan oleh Arch C. Luther dalam buku yang berjudul Authoring Interactive Multimedia yang pertama kali dipublikasikan pada tahun 1994. Luther membuat 6 tahapan proses dalam mengembangkan perangkat lunak multimedia dimulai dari tahap concept, design, collecting content material, assembly, testing, dan distribution.

\section{METODOLOGI PENELITIAN}

\section{A. Instrumen Penelitian \\ 1. Komputer}

Laptop Lenovo Y410P dengan prosesor Intel Core i7, Memori (RAM) 8GB, Dual VGA Intel \& Nvidia GT 750 $M$ (2 GB GDDR5), dan menjalankan sistem operasi Windows 8.1.

2. Unity $3 \mathrm{D}$

Unity 3D adalah game engine berbasis cross-platform yang dapat digunakan untuk membuat game di berbagai perangkat, diantaranya perangkat komputer, Mobile Android, windows, iPhone, PS3/PS4 dan X-Box.

3. Vuvoria SDK

Vuforia SDK adalah Software Development Kit berbasis AR yang digunakan untuk perangkat mobile, dan berfungsi untuk membuat aplikasi Augmented Reality. Vuforia memiliki metode untuk meproses, menganalisa, dan memetakan suatu gambar dalam resolusi tinggi menggunakan data dari dunia nyata menjadi informasi digital.

4. Adobe Software

Perangkat lunak multimedia dari adobe yang digunakan, berupa Flash professional untuk membuat animasi 2D, Photoshop untuk membuat konten-konten yang dibutuhkan animasi, After effect untuk menambahkan efek animasi, Premiere pro untuk menyusun keseluruhan video animasi beserta suara animasi.

\section{B. Identifikasi Masalah}

Melalui proses wawancara, pembagian kuesioner, dan memabca referensi dari penelitian-penelitian yang telah dilakukan sebelumnya, peneliti menemukan masalah mengenai kurangnya media sosialisasi untuk para calon mahasiswa baru mengenai langkah-langkah dalam 
melakukan pendaftaran di Universitas Sam Ratulangi Manado yang menyebabkan mereka merasa kesulitan dalam melakukan pendaftaran.

\section{Pengumpulan Data}

Metode pengumpulan data yang digunakan peneliti pada penelitian ini terdiri dari :

\section{Kuesioner}

Kuesioner di distribusikan kepada para siswasiswi kelas 12 sekolah menengah atas di Manado dengan umur antara 16 - 18 tahun yang memiliki kemungkinan akan melanjutkan pendidikan di perguruan tinggi.

2. Wawancara

peneliti mewawancarai salah satu staff yang bertanggung jawab untuk proses penerimaan mahasiswa baru di Universitas Sam Ratulangi Manado.

\section{Metode Pengembangan Perangkat Lunak}

Metode pengembangan perangkat lunak yang digunakan adalah metode Multimedia Development Life Cycle $(M D L C)$ yang terdiri dari 6 tahap, yaitu Tahap Pengonsepan, Tahap Desain, Tahap Pengumpulan materi, Tahap Perakitan, Tahap Pengujian, dan Tahap Distribusi.

\section{Tahap Pengonsepan}

Setelah mendapatkan semua data yang dibutuhkan, penelti akan mulai menentukan konsep dari perangkat lunak yang akan dibuat, fungsi perangkat lunak serta konten multimedia didalamnya. Konsep perangkat lunak yang dibuat dapat dilihat pada tabel 1 dibawah ini.

Tabel 1. Konsep perangkat lunak

\begin{tabular}{|l|l|}
\hline \multicolumn{1}{|c|}{$\begin{array}{c}\text { Kebutuhan } \\
\text { Aplikasi }\end{array}$} & \multicolumn{1}{|c|}{ Keterangan } \\
\hline Judul & $\begin{array}{l}\text { Animasi prosedur pendaftaran calon } \\
\text { mahasiswa baru Universitas Sam } \\
\text { Ratulangi dengan Augmented Reality }\end{array}$ \\
\hline Tujuan & $\begin{array}{l}\text { Memberikan informasi prosedur } \\
\text { pendaftaran calon mahasiswa baru } \\
\text { Universitas Sam Ratulangi Manado } \\
\text { dengan teknologi Augmented Reality }\end{array}$ \\
\hline Image & $\begin{array}{l}\text { Menggunakan format file .jpg dan } \\
\text { png untuk konten animasi dan } \\
\text { kebutuhan antarmuka aplikasi }\end{array}$ \\
\hline Audio & $\begin{array}{l}\text { Menggunakan format mp3. Dan wav } \\
\text { untuk kebutuhan animasi }\end{array}$ \\
\hline Video & $\begin{array}{l}\text { Video yang akan ditampilkan secara } \\
\text { Augmented Reality (AR) adalah } \\
\text { video animasi 2 dimensi } \\
\text { menggunakan format .m4v }\end{array}$ \\
\hline $\begin{array}{l}\text { Konten } \\
\text { multimedia }\end{array}$ & $\begin{array}{l}\text { Calon mahasiswa baru yang akan } \\
\text { mendaftarkan diri di Universitas Sam } \\
\text { Ratulangi Manado }\end{array}$ \\
\hline Penggunaan & $\begin{array}{l}\text { Animasi 2 dimensi } \\
\text { Warna dasar yang digunakan adalah }\end{array}$ \\
\hline
\end{tabular}

\begin{tabular}{|l|l|}
\hline warna & $\begin{array}{l}\text { Biru muda } \\
\text { Putih }\end{array}$ \\
\hline Ukuran aplikasi & $\begin{array}{l}\text { Keseluruhan aplikasi akan berukuran } \\
\leq 40 \mathrm{MB}\end{array}$ \\
\hline Platform & $\begin{array}{l}\text { Aplikasi akan berjalan di perangkat } \\
\text { mobile (smartphone) dengan sistem } \\
\text { operasi minimal adalah android versi } \\
4.1 \text { (Jelly bean) }\end{array}$ \\
\hline Input & Video animasi 2 dimensi \\
\hline Output & $\begin{array}{l}\text { Video animasi 2 dimensi dalam } \\
\text { bentuk Augmented Reality (AR) }\end{array}$ \\
\hline
\end{tabular}

2. Tahap Desain

Pada tahap ini dilakukan perakitan diagram UML berupa Use Case dan Activity diagram untuk menjadi gambaran fungsi dan fitur fitur dari aplikasi, Story board dan tampilan antarmuka dari aplikasi untuk menjadi panduan alur aplikasi, dan melakukan tahap pra-produksi animasi yang meliputi penentuan ide cerita, story board animasi, dan desain sketsa untuk kebutuhan produksi. Use case aplikasi dapat dilihat pada gambar 1 .

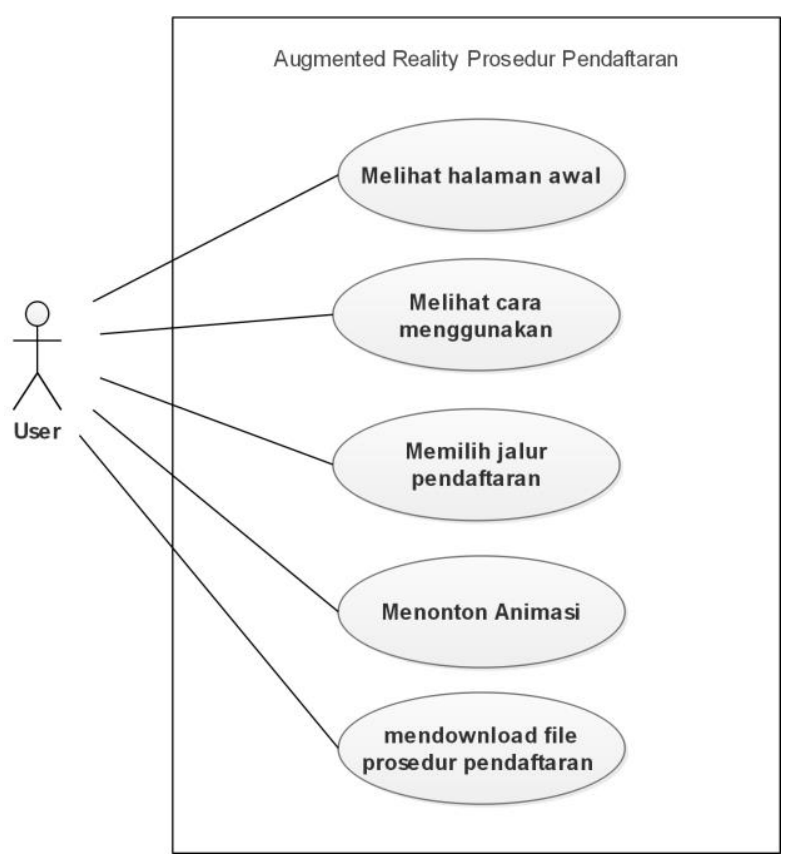

Gambar 1. Use Case Diagram Aplikasi

Activity Diagram memilih jalur pendaftaran yang ingin ditonton dan menonton video animasi dapat dilihat pada gambar 2 dan gambar 3 . 


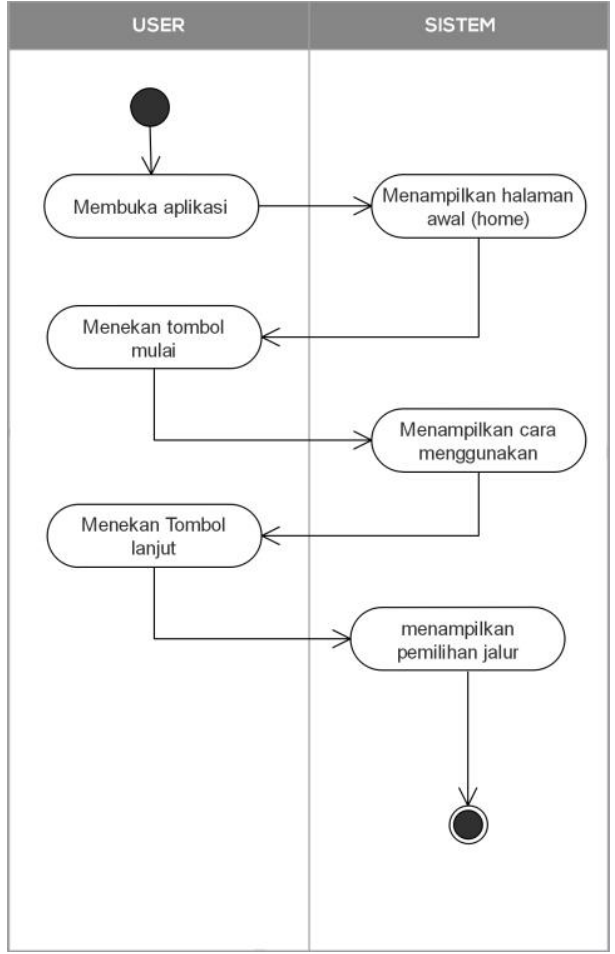

Gambar 2. Activity Diagram memilih jalur pendaftaran

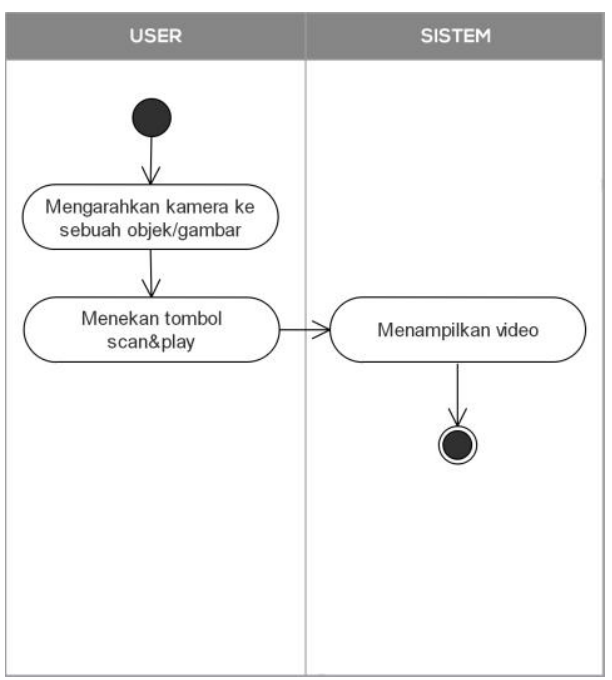

Gambar 3. Activity Diagram menonton video animasi

Desain story board antarmuka aplikasi ketika berada di tampilan menu pemilihan jalur pendaftaran yang ingin ditonton ditunjukan pada gambar 4 , dan antarmuka aplikasi ketika sedang menonton animasi secara augmented reality ditunjukan pada gambar 5 .

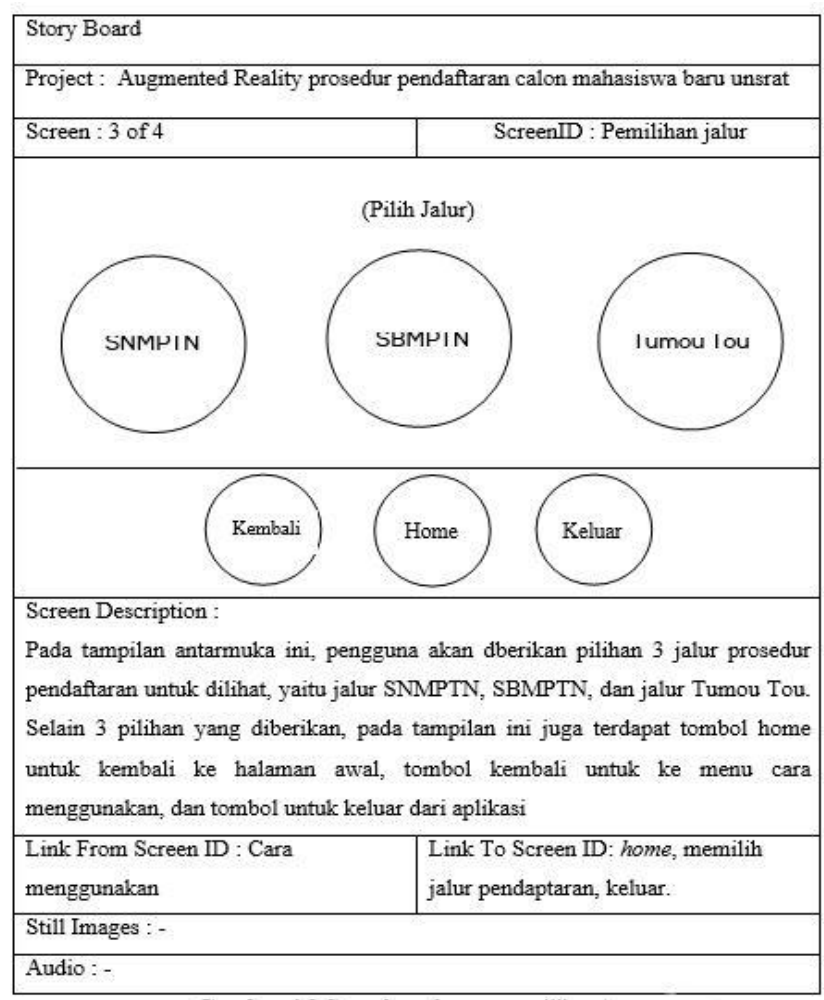

Gamar 4. Story board menu pemilihan jalur pendaftaran

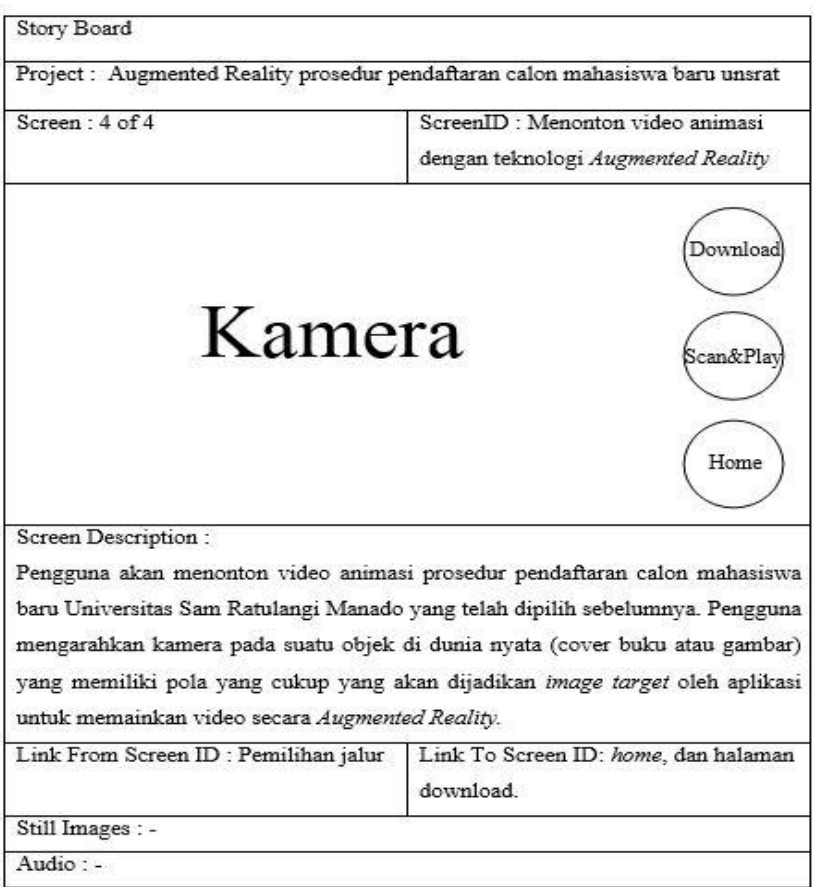

Gambar 5. Story board menonton video animasi

Alur penerimaan mahasiswa baru Universitas Sam Ratulangi Manado melalui jalur SNMPTN dapat dilihat pada gambar 6, jalur SBMPTN pada gambar 7, dan melalui jalur lokal Tumou Tou (T2) dapat dilihat pada gambar 8 . 


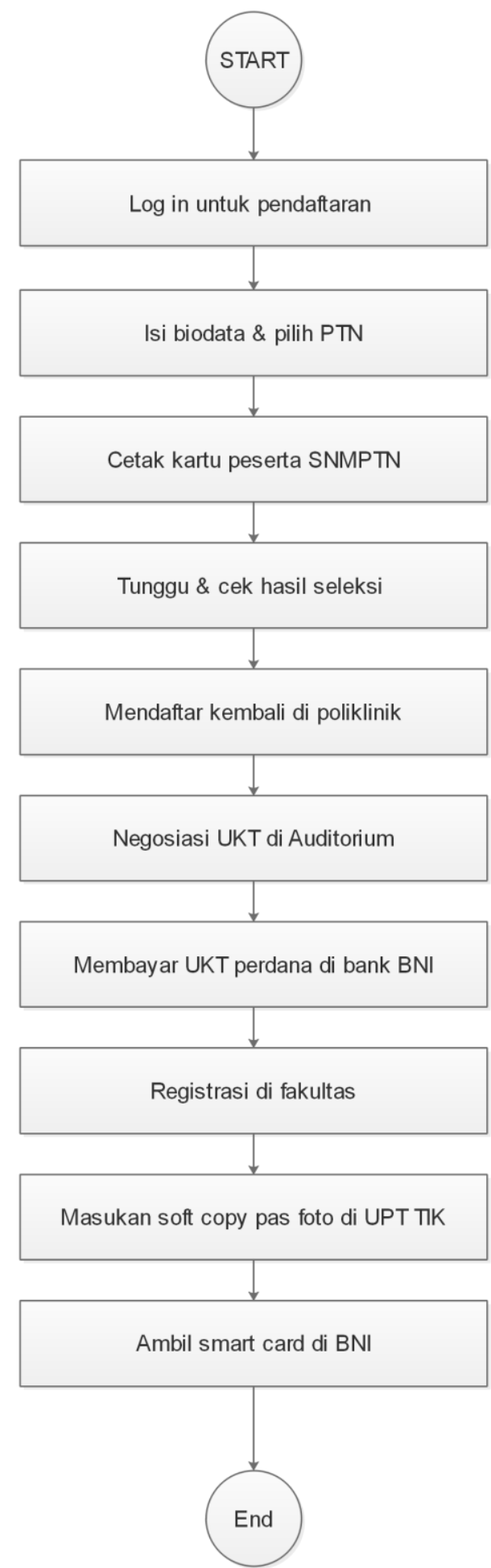

Gambar 6. Alur penerimaan mahasiswa baru melalui jaur SNMPTN

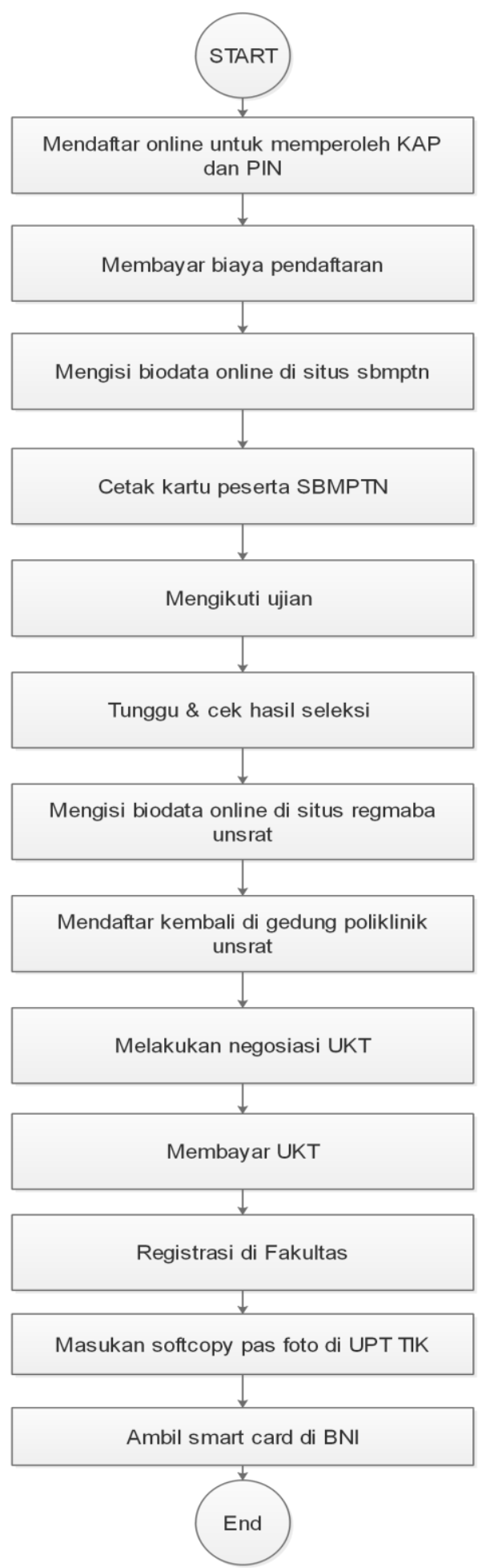

Gambar 7. Alur penerimaan mahasiswa baru melalui jaur SBMPTN 


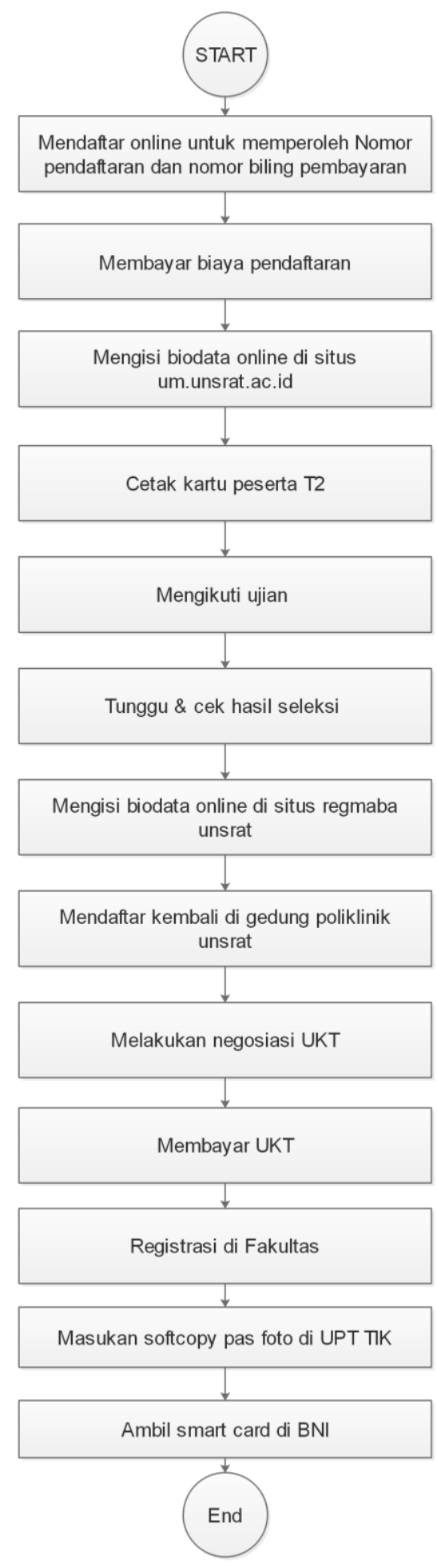

Gambar 8. Alur penerimaan mahasiswa baru melalui jaur Tumou Tou (T2)

\section{Tahap Pengumpulan Materi}

Pada tahap ini akan dilakukan pengumpulan bahan-bahan yang dibutuhkan dalam perakitan aplikasi. Pengumpulan material meliputi bahanbahan yang akan diimplementasikan pada antarmuka aplikasi, dan konten aimasi yang akan dipakai oleh aplikasi, untuk selanjutnya di bangun kedalam tahap perakitan.

\section{Tahap Perakitan}

Pada tahap ini, dilakukan pembuatan kode sumber untuk fungsi-fungsi dan keseluruhan aplikasi. Bahasa pemograman yang digunakan adalah bahasa pemograman $\mathrm{C \#}$ (C sharp).

\section{Tahap Pengujian}

Pengujian dari sisi pengembang dilakukan untuk memastikan fungsi-fungsi utama aplikasi berjalan dengan baik dan sesuai dengan persyaratan kebutuhan. Selain itu pengujian dilakukan untuk menemukan bug atau eror pada aplikasi agar dapat segera diperbaiki untuk selanjutnya di uji coba oleh pengguna. Pengujian dari sisi pengembang yang dilakukan pada aplikasi ini adalah menggunakan pengujian Alpha Test, kemudian dilanjutkan dengan eveluasi pengguna.

\section{Tahap Distribusi}

Aplikasi Augmented reality prosedur pendaftaran calon mahasiswa baru di distribusikan melalui Google Playstore yang merupakan pusat distribusi aplikasi Android.

\section{HASIL DAN PEMBAHASAN}

\section{A. Tampilan Menu Utama Aplikasi}

Tampilan antarmuka yang pertama kali akan dilihat oleh pengguna ketika membuka aplikasi. Tampilan ini untuk memperkenalkan pengguna dengan aplikasi augmented reality, untuk itu terdapat logo Universitas Sam ratulangi Manado dan logo augmented reality. Terdapat 2 tombol pada tampilan ini, tombol yang pertama adalah tombol "mulai" untuk navigasi ke tampilan selanjutnya, dan tombol "keluar" apabila pengguna ingin langsung keluar dari aplikasi. Tampilan halaman awal ditunjukan pada gambar 9.

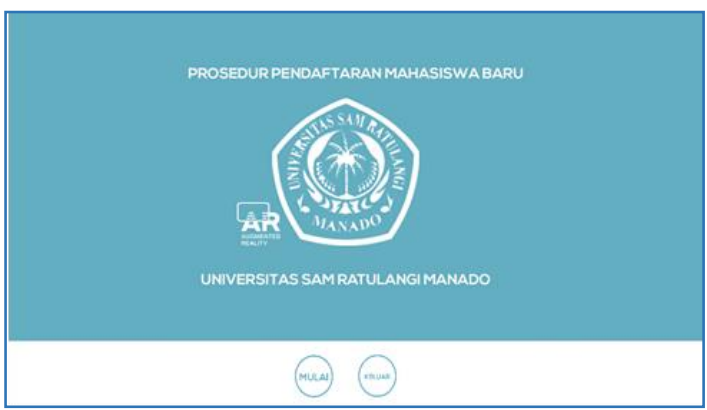

Gambar 9. Tampilan Menu Utama Aplikasi

\section{B. Tampilan Cara Menggunakan Aplikasi}

Tampilan cara menggunakan untuk memberitahu pengguna bagaimana cara menggunakan aplikasi untuk 
menonton video animasi prosedur pendaftaran. Tampilan cara menggunakan ditunjukan pada gambar 10 .

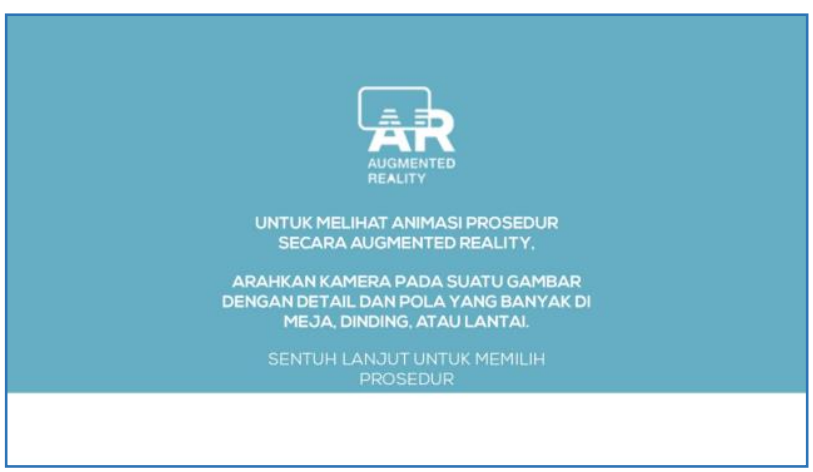

Gambar 10. Tampilan Cara Menggunakan Aplikasi

\section{Tampilan Menu Memilih Jalur Pendaftaran}

Pada tampilan ini pengguna bisa memilih jalur pendaftaran apa yang ingin dilihat, untuk itu terdapat 3 tombol pilihan jalur pendaftaran yaitu tombol SNMPTN untuk melihat jalur pendaftaran SNMPTN, tombol SBMPTN, dan tombol Tumou Tou. Tampilan cara menggunakan ditunjukan pada gambar 11 .

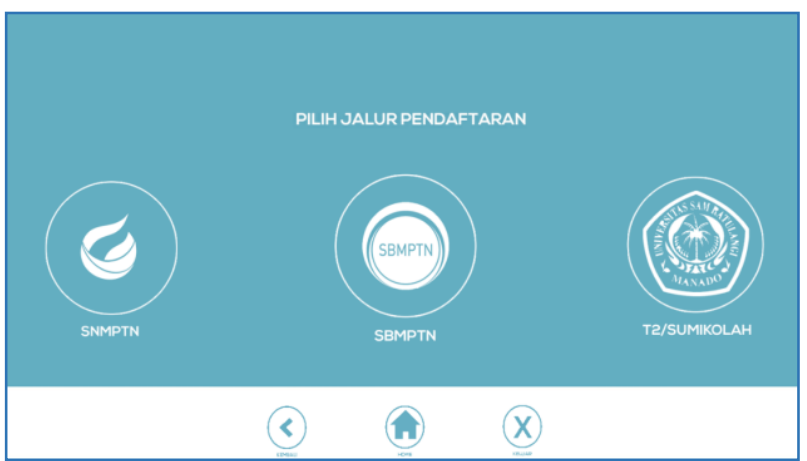

Gambar 11. Tampilan Menu Memilih Jalur Pendaftaran

\section{Tampilan Menonton Animasi Augmented Reality}

Tampilan dimana pengguna akan memindai image target untuk menonton video secara Augmented Reality. Terdapat 3 tombol pada tampilan ini, yaitu tombol untuk memindai image target, tombol untuk mendownload file, dan tombol navigasi untuk kembali ke tampilan awal aplikasi. Tampilan menonton animasi Augmented Reality dapat dilihat pada gambar 12 .

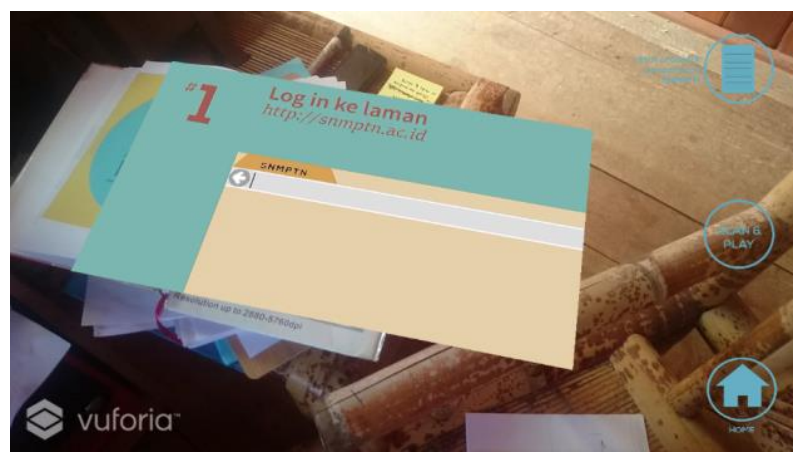

Gambar 12. Tampilan Menonton Animasi Augmented reality

\section{E. Hasil Pengujian}

\section{Alpha Test}

Hasil pengujian dari sisi pengembang dengan menggunakan pengujian Alpha Test dapat dilihat pada tabel 2 .

Tabel 2. Hasil Pengujian Alpha Test

\begin{tabular}{|c|c|c|c|c|}
\hline \multirow[t]{2}{*}{ No } & \multirow[t]{2}{*}{ Item Pengujian } & \multicolumn{2}{|c|}{ Hasil } & \multirow[t]{2}{*}{ Keterangan } \\
\hline & & Baik & Tidak & \\
\hline 1 & Halaman awal & $\checkmark$ & & Berhasil \\
\hline 2 & $\begin{array}{l}\text { Halaman cara } \\
\text { menggunakan }\end{array}$ & $\checkmark$ & & Berhasil \\
\hline 3 & $\begin{array}{c}\text { Halaman } \\
\text { pemilihan jalur } \\
\text { pendaftaran }\end{array}$ & $\checkmark$ & & Berhasil \\
\hline 4 & Tombol mulai & $\checkmark$ & & Berhasil \\
\hline 5 & Tombol Lanjut & $\checkmark$ & & Berhasil \\
\hline 6 & Tombol kembali & $\checkmark$ & & Berhasil \\
\hline 7 & $\begin{array}{c}\text { Tombol halaman } \\
\text { utama }\end{array}$ & $\checkmark$ & & Berhasil \\
\hline 8 & Tombol keluar & $\checkmark$ & & Berhasil \\
\hline 9 & Tombol SNMPTN & $\checkmark$ & & Berhasil \\
\hline 10 & Tombol SBMPTN & $\checkmark$ & & Berhasil \\
\hline 11 & $\begin{array}{c}\text { Tombol Tumou } \\
\text { Tou }\end{array}$ & $\checkmark$ & & Berhasil \\
\hline 12 & Video SNMPTN & $\checkmark$ & & Berhasil \\
\hline 13 & Video SBMPTN & $\checkmark$ & & Berhasil \\
\hline 14 & Video Tumou Tou & $\checkmark$ & & Berhasil \\
\hline 15 & $\begin{array}{l}\text { Tombol download } \\
\text { file SNMPTN }\end{array}$ & $\checkmark$ & & Berhasil \\
\hline 16 & $\begin{array}{l}\text { Tombol download } \\
\text { file SBMPTN }\end{array}$ & $\checkmark$ & & Berhasil \\
\hline 17 & $\begin{array}{c}\text { Tombol download } \\
\text { file Tumou Tou }\end{array}$ & $\checkmark$ & & Berhasil \\
\hline
\end{tabular}

2. Evaluasi Pengguna

Evaluasi dilakukan untuk menilai hasil penelitian dan umpan balik penngguna terhadap aplikasi. Evaluasi dilakukan dengan mendistribusikan kuesioner kepada pengguna yang telah mencoba menggunakan aplikasi. 
Dari kuesioner yang telah di distribusikan, dapat ditarik kesimpulan dimana $87.8 \%$ responden setuju bahwa merka bisa mengetahui langkah-langkah pendaftaran di Universitas Sam Ratulangi Manado melalui aplikasi ini, $80 \%$ dari responden setuju bahwa aplikasi ini akan mengurangi kesulitan ketika melakukan pendaftaran di Universitas Sam Ratulangi Manado, 85\% menyatakan bahwa aplikasi ini memberikan gambaran umum yang jelas pengenai langkah langkah prosedur pendaftaran di Universitas Sam Ratulangi Manado, 84\% responden setuju bahwa mereka mendapatkan pengalaman baru dengan teknologi augmented reality dan $82.8 \%$ responden menyatakan aplikasi ini memberikan informasi dengan baik.

\section{PENUTUP}

\section{A. Kesimpulan}

Kesimpulan yang diambil dari pembuatan Animasi Prosedur Pendaftaran Mahasiswa Baru Universitas Sam Ratulangi dengan Augmented Reality adalah :

1. Dengan menggunakan tools vuvoria sdk dan mesin game unity 3D, animasi 2 dimensi untuk memberikan informasi prosedur pendaftaran mahasiswa baru Universitas Sam Ratulangi dapat diimplementasikan dengan teknologi augmented reality.

2. Aplikasi telah dibuat dan diselesaikan.

3. Aplikasi dapat memberikan informasi mengenai setiap jalur dan prosedur pendaftaran yang ada di Universitas Sam Ratulangi Manado kepada calon mahasiswa baru yang ingin mendaftarkan diri sehingga mengurangi kesulitan mereka memperoleh informasi mengenai langkah yang harus dilakukan ketika mereka mendaftarkan diri di Universitas sam ratulangi Manado.

4. Penggunaan teknologi Augmented Reality memberikan pengalaman baru bagi para calon mahasiswa yang belum pernah mengetahui tentang keberadaan teknologi ini.

B. Saran

Setelah penelitian diselesaikan, maka disarankan

1. Pengembangan selanjutnya menambah konten informasi mengenai prosedur-prosedur lain yang ada di Universitas Sam Ratulangi Manado.

2. Ukuran dari aplikasi untuk bisa di kurangi agar lebih mudah untuk di unduh dan tidak mengkonsumsi media penyimpanan di perangkat mobile smartphone.

3. Pengembangan selanjutnya untuk menambah platform agar aplikasi bisa dijalankan juga di platform $i O S$.

\section{DAFTAR PUSTAKA}

[1] Azuma, R.T. 1997. A Survey of Augmented Reality. Teleoperators and Virtual Environments, Vol. 6, No. 4, pp. 355-385.

[2] Arch, C.L. 1994. Authoring Interactive Multimedia. AP Professional, Inc. San Diego, CA, USA.
[3] Brian, W. Frame Of Reference : Toward a Definition of Animation. Animation Practice, Process, and Production, Vol 1, No 1.

[4] Darma, J.S., Shenia A. 2009. Buku Pintar Multimedia. MediaKita.

[5] Dharwiyanti, S., Wahono, R.S. 2003. Pengantar Unified Modeling Language (UML). Kuliah Umum IlmuKomputer.com.

[6] Fukharen, F. 2015. Perancangan Video Motivasi Animasi 2D Untuk Buku Terlaris di Dunia "Who Moved My Cheese ?". Program Studi Teknik Informatika, STMIK TIME

[7] Informasi "SNMPTN 2017" [Online]. Available : http://snmptn.ac.id/informasi.html?1426322267. Diakses tanggal 28 April 2017.

[8] Informasi umum "SBMPTN" [Online]. Available : http://sbmptn.ac.id/?mid=13. Diakses tanggal 28 April 2017.

[9] Karouw, S., Rarymangkay, J., Rawis, Z. 2014. Pemodelan Proses Bisnis Admisi Calon Mahasiswa Baru di Universitas Sam Ratulangi. Jurnal Teknik Informatika. Universitas Sam Ratulangi Vol. 3, No 1.

[10] Lengkey, M., Rindengan, Y., Tulenan, V. 2014. Brosur Fakultas Teknik Universitas Sam Ratulangi Manado dengan Teknologi Markerless Augmented Reality. E-journal Teknik Elektro dan Komputer. Universitas Sam Ratulangi Manado.

[11] Maramis, M., Lumenta, A., Sugiarso, B. 2016. Augmented Reality Pada Aplikasi Android Untuk Memperlihatkan Gedung Fatek. E-Journal Teknik Elektro Dan Komputer. Universitas Sam Ratulangi Manado. Vol. 5, No 1.

[12] Pressman, R.S. 2012. Rekayasa Perangkat Lunak : Pendekatan Praktisi Edisi 7. Penerbit Andi, Yogyakarta.

[13] Pangemanan, R., Sengkey, R., Lantang, O. 2016. Perancangan Animasi 3 Dimensi Alur Pengurusan Administrasi Pasien Umum dan Jaminan di Bagian Rehabilitasi Medik RSUP Prof. DR. R.D Kandou Manado. E-Journal Teknik Informatika. Universitas Sam Ratulangi Manado. Vol.9, No 1.

[14] Putri, D., Deddy, A., Bunyamin. 2014. Perancangan Aplikasi Media Pembelajaran Pendidikan Lingkungan Hidup Untuk Siswa Kelas VI Sekolah Dasar Berbasis Android. Jurnal STT Garut.

[15] Rahman, C. 2015. Perancangan Simulasi Animasi 2D Tata Cara Pemberian Suara Pada Pemilihan Umum Menggunakan Metode Rotoscoping (Studi Kasus : Komisi Pemilihan Umum Kabupaten Deli Serdang). Pelita Informatika Budi Darma, STMIK Budidarma, Medan. Vol. 9, No 1.

[16] Rinaldi, J., Rumagit A.M., Lumenta A.S.M., Wowor, A.P.R. Perancangan Tutorial Penerimaan Mahasiswa baru Universitas Sam Ratulangi Berbasis Animasi 3D. Teknik Elektro Fakultas Teknik, Universitas Sam Ratulangi Manado.

[17] Riady, S., Sentinuwo, S., Karouw, S. 2016. Rancang Bangun Aplikasi Mobile Learning Anak Sekolah Minggu dengan Teknologi Augmented Reality Berbasis Android. Teknik Informatika, Universitas Sam Ratulangi Manado. Vol. 9, No 1.

[18] Rumbaugh, J., Jacobson I., Grady Booch. The Modeling Language Reference Manual. AddisonWesley. 
[19] Senduk, E., Sinsuw, A., Karouw, S. 2016. MLearning Pendidikan Karakter untuk Anak Usia Dini Berbasis Augmented Reality. E-Journal Teknik Informatika. Universitas Sam Ratulangi Manado. Vol. 9, No 1.

[20] Sutopo, H. 2011. Aplikasi Multimedia Dalam Pembelajaran. Workshop Pengembangan Pembelajaran Berbasis Multimedia, Tangerang.

[21] Umafagur, F. 2016. Implementasi Virtual Tour Sebagai Media Informasi Daerah (Studi Kasus : Kota Manado). Skripsi Program S1 Program Studi Tekik Informatika Universitas Sam Ratulangi Manado.

[22] Situs Resmi Android Developer [Online]. Available : https://developer.android.com. Diakses tanggal 28 April 2017.

[23] Situs Resmi vuvoria library [Online]. Available : https://library.vuforia.com/. Diakses tanggal 28 April 2017.

\section{SEKILAS TENTANG PENULIS}

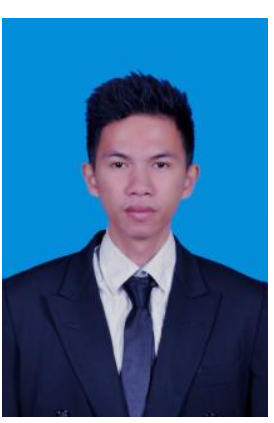

Sekilas dari penulis dengan nama Riki Satria Watulingas, anak pertama dari dua bersaudara. Lahir di Kapataran, 31 Agustus 1995. Dengan latar belakang pendidikan Sekolah Dasar (SD) Inpres Kapataran, Sekolah Menengah Pertama (SMP) Negeri 1 Lembean Timur dan berhasil lulus pada tahun 2009. Setelah itu melanjutkan pendidikan di Sekolah Menengah Kejuruan (SMK) Kristen 1 Tomohon dan lulus pada tahun 2012. Penulis kemudian melanjutkan studi di Fakultas Teknik, Jurusan Elektro, Program Studi Informatika, Universitas Sam Ratulangi Manado. Pada tahun 2017 penulis membuat skripsi demi memenuhi syarat Sarjana (S1) dengan penelitian berjudul "Animasi Prosedur Pendaftaran Calon Mahasiswa Baru Universitas Sam Ratulangi dengan Augmented Reality" 
E-Journal Teknik Informatika Vol 12, No.1 (2017) ISSN: 2301-8364 
E-Journal Teknik Informatika Vol 12, No.1 (2017) ISSN: 2301-8364 